\section{Forty-Sixth Class of \\ Congressional Fellows \\ Begins 1998-99 Program}

As the APSA Congressional Fellowship Program (CFP) prepares to welcome its 46th class, it does so with more than the usual imponderables of an off-year congressional election cycle and the uncertainties of whether the incumbent members with whom the fellows interview will all return for the 106th Congress.

This year, there is the added ingredient of the report of the independent counsel and a U.S. House of Representatives consideration of presidential impeachment.

Apart from the practicalities of seeking an office assignment, this puts an added burden on the CFP staff to book November orientation speakers.
Fortunately, the CFP has among its loyal and generous stable of guest speakers some of the best-informed observers of Congress in the country. Among those political scientists who have traditionally provided our academic perspective will be Norman Ornstein of the American Enterprise Institute, Tom Mann of the Brookings Institution, Professors James Thurber, Susan Hammond,

\title{
Technological Changes Promote Better Service at the National Office
}

APSA's national office is constantly growing and changing in an effort better to meet members' needs. This fall, several major technology changes have occurred at the national office. We have recently completed a major upgrade of our computing capabilities and are in the midst of a major extension of our web site, APSANet (www.apsanet.org), all in order to provide faster, more efficient, more accurate service.

\section{Association Management Software}

Slightly more than a year ago, we began researching the feasibility of upgrading our membership and meetings database. We had been using our previous UNIX-based database for six years, and we were rapidly outgrowing the package's capabilities and format. The week after we returned from Boston, we replaced the old database with a Windows-based package that takes advantage of current technology, particularly the latest version of Microsoft Access. At the same time, we also upgraded our accounting software. The old system was permanently shut down in mid-October. Although the transition has been challenging for all APSA staff members, this new program will allow us to work more efficiently, provide information in a more flexible manner, and link more easily with the other programs, including email and the web, we use regularly in the national office.

\section{APSANet}

The APSA web site, redesigned in September 1997, contains a wealth of information on the Association and political science in general. Since September 1997, we have made great strides in both the quality and the content of the site. Our most significant development was institution of a web-based Annual Meeting Call for Papers. Of the nearly 7000 proposals submitted for the 1998 Annual Meeting, over $50 \%$ were received via the online forms.

This past spring, we began the process of taking the Personnel Service Newsletter online, unfolding in a two stage process. Stage one involved allowing departments to submit job listings via a special online form. The listings are maintained in a database where the PSN editor may access a complete log of job listings formatted for publication. In stage two, which began June 1, PSN was made fully available online, with access passwordrestricted to subscribers.

We are currently expanding

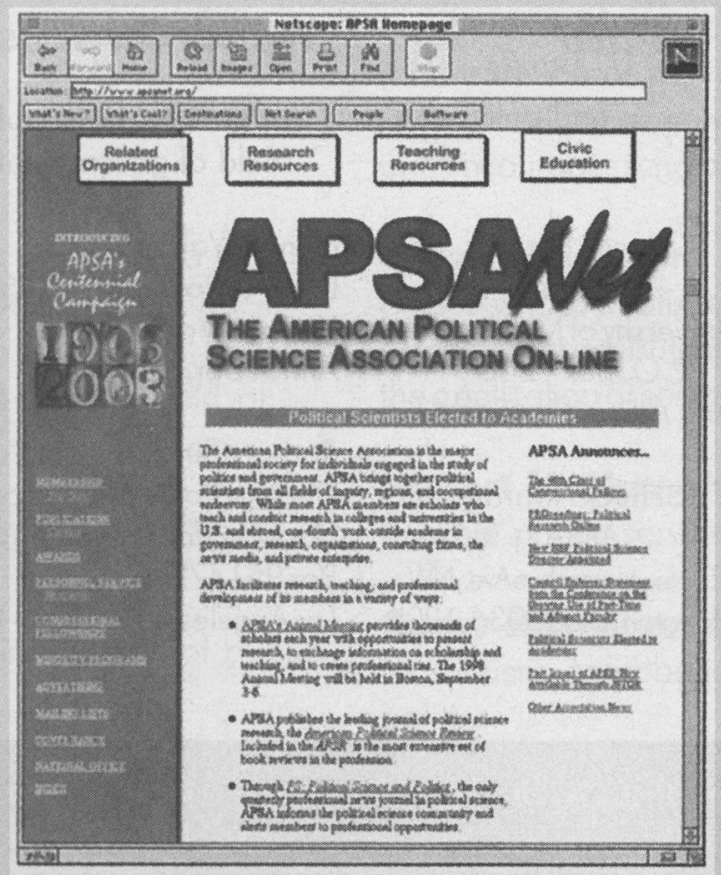
CENnet, our new civic education site (www.apsanet.org/ CENnet/), which already includes essays from the this Constitution series and PS, an address book of scholars and organizations in the United States and abroad working in civic education, and materials prepared by the APSA Task Force on Civic Education. Soon, the site will also have links to classroom materials and essays for teachers. Additionally, we launched PSonline this fall, the web version of this journal, which includes time-sensitive materials such as calls for papers, fellowship and grant information, and upcoming meeting and conference details. 


\section{Nominations Sought for \\ 1999 APSA Book Awards}

Nominations are invited for APSA Book Awards to be presented at the 1999 Annual Meeting, September 2.5, in Atlanta. Books published in 1998 may be nominated by publishers or individuals who submit nominations. The deadline for submission of books to an award committee is February 15, 1999. A list of 1999 Book Award Committees and their addresses follows:

\section{Ralph J. Bunche Award}

For the best scholarly work in political science which explores the phenomenon of ethnic and cultural pluralism

Charles Henry

U. ofCalifomia, Berkeley

200 California Hall

Berkeley, CA94720

Richard Shingles

Dep't of Political Science

Virginia Tech

Blacksburg, VA24061-7874

\section{Gladys M. Kammerer Award}

for the best political science publication in the field of U.S. national policy
Helen Ingram

School of Ecology, URP

$U$. of California, Irvine

202Social Ecology 1

Invine, CA92697

Matthew J. Dickinson

385 Maiden Lane

P.O. Box 114

Ripton, VT05766
Dean Yarwood Dep't of Political Science University of Missouri 113 Professional Bldg. Columbia, MO 65211

KammererAward APSA

1527NewHampshireAve., NW Washington, DC20036-1206

\section{Victoria Schuck Award}

For the best book published on women and politics.

Marjorie Lewis

Grad. School of Public Affairs

University of Colorado

1380 Lawrence St., \#600

Denver, CO 80202

Clyde Wilcox

1653 Trap Road

Vienna, VA22182

\author{
Nancy Burns \\ 3063ISR \\ University of Michigan \\ P.O. Box 1248 \\ Ann Arbor, MI 48106 \\ Schuck Award \\ APSA \\ 1527 NewHampshireAve.,NW \\ Washington, DC20036-1206
}

\section{Woodrow Wilson Foundation Award}

For the best book published in the United States in the field of government, politics or international affairs

Hanes Walton Jr.

Dept. of Political Science

University of Michigan

Ann Arbor, Ml 48109

BarbaraSinclair

Dept. of Political Science

U. of California, Los Angeles

Box 951472

LosAngeles, CA90095-1472
Randolph Siverson

Dept. of Politial Science

U. of California, Davis

OneShields Avenue

Davis, CA95616

Wilson Award APSA

1527 NewHampshireAve., NW

Washington, DC20036-1206

For further information visit the APSA web site at Www.apsanet.org or

contact Sean Twombly at the national office by phone (202) 483-2512

or via email at twombly@apsanet.org. 


\section{- \\ Nominations Sought for 1999 APSA Awards}

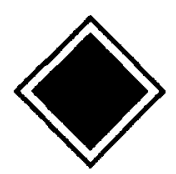

Nominations are invited for APSA Career and Dissertation Awards to be presented at the 1999 Annual Meeting, September 2-5, in Atlanta, Georgia.

Departments are invited to submit nominations for dissertation prizes, although not more than one per award. Dissertations eligible are those completed and accepted during the past two acadmic years. Department submissions should be sent to each member of the award committee and include a letter of nomination and a copy of the dissertation. A copy of the nomination letter only should be sent to the APSA national office. Departments must submittheir nominations by January 15, 1999.

Individuals are also invited to submit, for consideration, letters of nomination for APSA-sponsored Career Awards. Career Awards are decided upon by three-member committees appointed by the president and approved bythe Council. The deadline for submission of letters is February 1, 1999.

\section{Dissertation Prizes}

Gabriel A. Almond Award - in the field of comparative politics.

William Anderson Award - in the field of state and local politics, federalism and intergovernmental relations.

Edward S. Corwin Award - in the field of public law.

Harold D. Lasswell Award - in the field of policy studies.

Helen Dwight Reid Award - in the field of international relations, law and politics.

E.E. Schattschneider Award - in the field of American government.

Leo Strauss Award - in the field of political philosophy.

Leonard D. White Award - in the field of public administration.

\section{Career Awards}

James Madison Award - presented triennially to honor an American political scientist who has made a distinguished contribution to political science. The award is designed to recognize a career of scholarly excellence rather than a particular piece of scholarship.

John Gaus Award and Lectureship - to honor a recipient's lifetime of exemplary scholarship in the joint tradition of political science and public administration and more generally, recognizes achievement and encourages scholarship in publicadministration.

Charles Merriam Award - given biannually to a person whose published work and career represents a significant contribution to the art of government through the application of social science research.

Hubert H. Humphrey Award - in recognition of notable public service by a political scientist.

Carey McWilliams Award - to honor a major journalistic contribution to our understanding of politics. 
Hammond, and Candice Nelson of American University, Professor Christopher Deering of George Washington University, and Professor Roger Davidson of the University of Maryland. Among the new political scientists addressing the Fellows will be Professor and former Fellow Larry Evans of William and Mary and William Koetzel, a Fellow from the 1997-98 class who has remained within the House Republican leadership on the staff of Majority Deputy Whip Rep. J. Dennis Hastert (R-IL).

So Fellows receive the journalists' perspective, November orientation speakers will also include The Washington Post's David Broder, The Wall Street Journal's Al Hunt, ABC News and National Public Radio's Cokie Roberts, former Congressional Fellow and current political editor for USA Today Ron Elving, NBC News' Andrea Mitchell, and Los Angeles Times bureau chief Doyle McManus.

Helping the Fellows bridge the not entirely distinct worlds of academe, the press, and politics will be a two-day orientation on legislative mechanics sponsored by the Library of Congress' Congressional Research Service that will include presentations by Dan Mulhollan, Walter Oleszek, Stan Bach, Lou Fisher, and Judy Schneider. Other authoritative orientation voices will include Alan Ehrenhalt's, editor of Governing; Alton Frye's, senior vice president of the Council on Foreign Relations and a former Fellow; Gary Hymel, senior vice president at Hill and Knowlton and former chief-ofstaff to Speaker Tip O'Neill; Brian Lamb, C-SPAN CEO; Celinda Lake, president of Lake Research; and the staff of the Heritage Foundation.

Among the most essential aspects of any orientation program are those current congressional staffers and former Congressional Fellows who form a series of panel discussions focused on the everyday life on "The Hill." Blessed as the CFP is with a cast of well-known experts, there are few people better prepared to offer advice on the nittygritty of serving as a congressional staffer than our own former Fellows. The goal of the orientation, after all, is to prepare Fellows for their re-

\section{Washington Insider}

\section{More Words on Affirmative Action Bans in College Admissions}

Thirty-five students from underrepresented minority groups, nine of whom are black, entered law school at the University of California, Berkeley in the fall of 1998. In 1997, only 15 minority students, one of whom is black, enrolled. Cut another way, minorities constituted $13 \%$ of the incoming class in 1998, down from the $20 \%$ in 1996 (before the affirmative action ban was put in place), but substantially higher than the $6 \%$ they comprised in 1997. School administrators attribute the increase in minority enrollments to aggressive recruiting and flexible admissions criteria that call for less consideration of standardized test scores. Programs similar to UC's are being implemented in Oklahoma, Texas, Minnesota, and several other states.

\section{House Report on Status, Future of Science Policy Leaves out Social Science}

On October 7, the U.S. House declared Unlocking Our Future: Toward a New Science Policy should "serve as a framework for future deliberations on congressional science policy and funding." A year in preparation and authored by Vern Ehlers (R-MI), the report is being touted as replacement to Vannevar Bush's seminal 1945 call to action, Science: The Endless Frontier. The new report's theme is that the U.S. "must maintain and improve its preeminent position in science and technology in order to advance human understanding of the universe . . . and to improve the lives, health, and freedom of all people." Calling science "a critical driver of the nation's economy," the report urges Congress to "make stable and substantial federal funding for fundamental scientific research a priority" and praises public-private partnershihps, stresses the need for better science education at all levels, and asks for greater reliance upon sound science when making policy. With the exception of a single footnote indicating that the definition of science used for preparing the report includes social science, the report contains no mention of social science. In a press release accompanying the report, Committee member George Brown (D-CA), decried the narrow focus and noted that "an argument can be made that the most pressing issues facing our society-crime, education reform, social justice-are likely to be addressed through investment in the social sciences rather than in the hard science." The report is available for review and comment on the Science Committee's home page (www.house.gov/science/science_policy_study.htm).

\section{Republicans Win Initial Cases to Block Sampling in 2000 Census}

On August 24, a three-judge panel of the District Court for the District of Columbia unanimously ruled that the Clinton administration's plan to use statistical sampling in the 2000 Census did not meet the requirements set for "an enumeration" of the country's population as the term is defined in the Constitution and Title 13 of the United States Code. An identical ruling was issued by a three-judge panel in a case brought by the Southeastern Legal Foundation before the U.S. District Court for the Eastern District of Virginia. The challenge in the first case was filed in the name of the U.S. House of Representatives by Census Subcommittee Chairman Dan Miller (R-FL). The U.S. Department of Justice filed an appeal and secured an agreement from the U.S. Supreme Court to expedite consideration of the case. Arguments will be heard on November 30, 1998, and a decision has been promised by March 30, 1999. In the interim, the Census Bureau is proceeding with a "dual-track" planning process for the upcoming census-preparing plans for a count that uses statistical sampling and another that does not.

\section{House Passes Digital Database Copyright Bill, But It's Killed in Conference}

In early August, the U.S. House passed the "Collections of Information Antipiracy Act" (H.R. 2652). Widely criticized as inimical to legitimate research efforts, the "database bill" imposes a narrow interpretation of fair use onto collections of data archived and available in electronic format. The summary of the Bill, which was referred to the Senate in August but was dropped from the slew of copyright legislation passed in mid-October, which included the Digital Millenium Copyright Act and Copyright Term Extension Act, states, in part, that the Act "amends Federal copyright law to make person who extract, or use in commerce, a substantial part of a collection of information gathered or maintained by another person ... so as to harm the other person's ... actual or potential market for a product or service that incorporates such information and is offered or intended to be offered in commerce liable to the person... for [civil] remedies under this Act." Exemptions to the Act specifically include "extraction or use of individual items of information or extraction or use of information for verification, nonprofit educational, scientific, or research, or news reporting purposes." The full text of the Act, along with summary and referral reports, can be found on the U.S. Copyright Office web site (http://laweb.loc.gov/copyright/penleg.html). It will be reintroduced in the next Congress. 
ponsibilities as legislative assistants to members of the Congress. Fellows are scheduled to begin working on Capitol Hill in early December.

For more information on the Congressional Fellowship Program, contact Congressional Fellowship Program, APSA, 1527 New Hampshire Avenue, NW, Washington, DC 200361206; (202) 483-2512; Fax: (202) 4832657; Email: cfp@apsanet.org; www.apsanet.org/CFP.

\section{Disability Income Now Available to APSA Members}

A Disability Income plan with monthly benefits of $\$ 1000, \$ 2000$, or $\$ 3000$ is now available to members of the APSA.

All APSA members and their spouses/domestic partners are eligible (upon meeting certain requirements) for up to five full years of guaranteed income if disabled by a covered accident, and up to one full year if disabled by a covered illness. Benefits are payable in addition to income from other sources, up to $70 \%$ of the recipient's monthly salary.

For more information on the APSA Disability Income Plan, contact Albert H. Wohlers \& Co., Attn: APSA Insurance Administrator, 1440 N. Northwest Highway, Park Ridge, IL 60068-1400; (800) 5039230; Email: cusv@ahw.com.

\section{APSA Organized Sections Distribute Awards at Annual Meeting}

As part of the 1998 Annual Meeting in the Boston, Organized

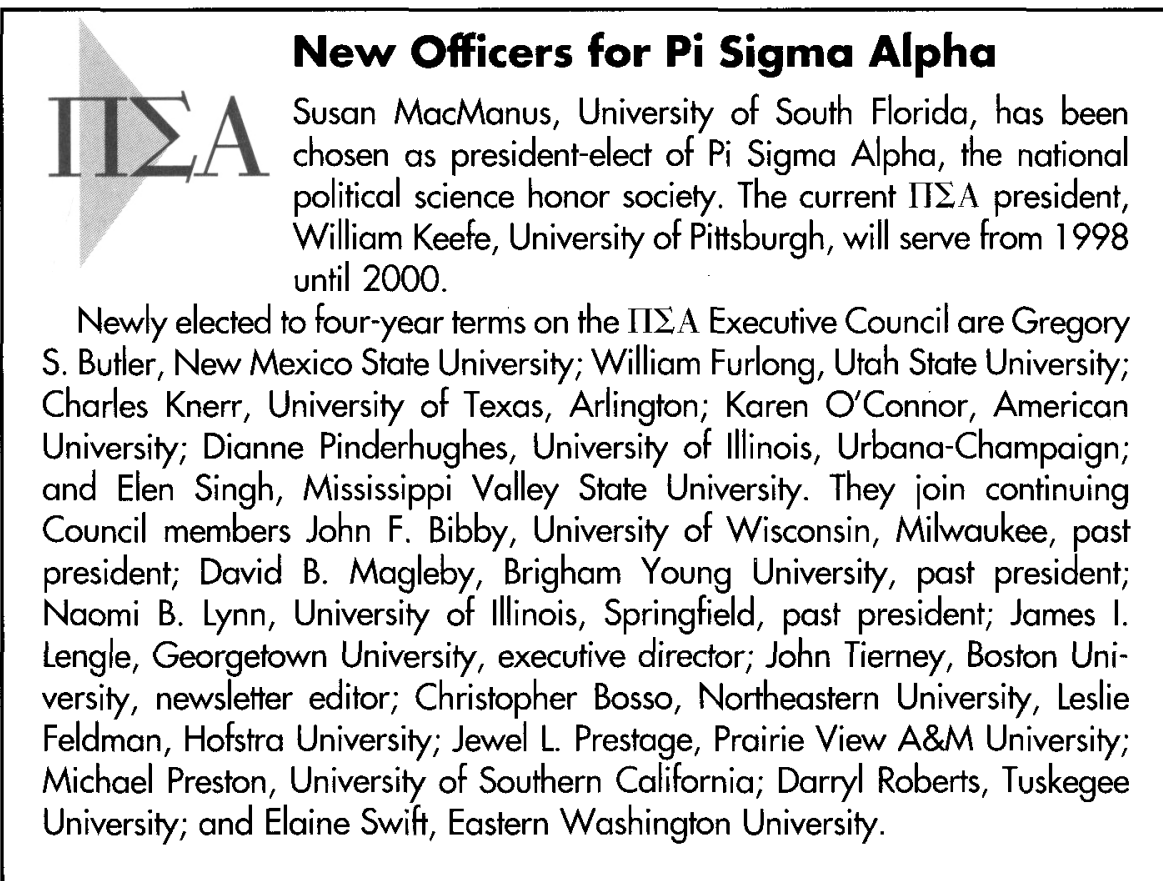

Sections of the Association presented nearly 50 awards recognizing dissertations, books, papers, and careers. Many of these Section prizes are annual and nominations are sought at this time for next year's awards. For further information visit the APSA web site (www.apsanet.org).

\section{Political Psychology}

The Best Book Award in Political Psychology was awarded to two outstanding publications in 1997, Shook Over Hell: Post Traumatic Stress, Vietnam, and the Civil War, by Eric T. Dean and System Effects: Complexity in Political and Social Life, by Robert Jervis of Columbia University.

\section{Federalism and Intergovernmental Relations}

The Distinguished Scholar Award recognizing distinguished scholarly contributions to the study of federalism and intergovernmental relations was presented to Paul E. Peterson of Harvard University. The Best Paper Award was conferred on Richard C. Elling and Lyke Thompson, Wayne State University, for "Let Them Eat Marblecake: Michigan Citizens' Preferences on Intergovernmental Structure." The award recognizes the best paper in the field of federalism and intergovernmental relations presented at the 1997 APSA Annual Meeting. The Best Book Award, for the best book on federalism and intergovernmental

\section{Listing of Doctoral Dissertation in Political Science Now Available Online}

For the first time, the annual listing of dissertations completed in political science is available on the web. Go to PSonline (mww.apsanet.org/PS/], click on Dissertations, and find the author, title, school, or subject you seek. No more six-point type. No more reading through dozens of uninteresting titles. No more failing to find the listings you seek due to fatigue, frustration, or faltering vision. Paper copies of the dissertation listing will be retained by APSA for archival purposes and will be sent to individuals without web access upon request from Editor, PS, American Political Science Association, 1527 New Hampshire Avenue, NW, Washington, DC 20036-1206; (202) 483-2512; Fax: (202) 483-2657.

www.apsanet.org/PS/dissertations98/ 